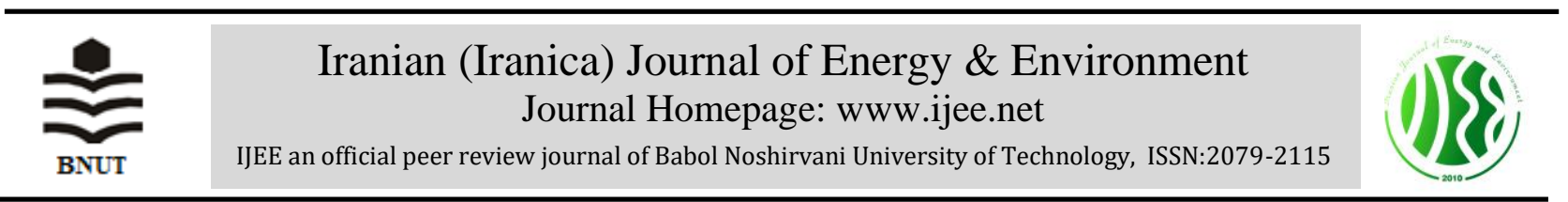

Short Communication

\title{
Current Status, Future Potential and Barriers for Renewable Energy Development in Ethiopia
}

\author{
A. Belay Kassa*
}

Mechanical Engineering Department, Institute of Technology, University of Gondar, Ethiopia

\section{$P A P E R \quad I N F O$}

Paper history:

Received 30 Octobrt 2019

Accepted in revised form 24 November 2019

\section{Keywords:}

Biomass

Geothermal

Hydro Power

Renewable Energy

Solar Energy

Wind Power

\begin{abstract}
A B S TRACT
Ethiopia is a land locked country, located in Horn of Africa. The country power generation does not meet the national demand of the people. The aim of the paper is to review a current status, future potential and barriers on development of renewable energy for power generations in Ethiopia. The approaches would be use of primary and secondary data. The structural question is developed and data collected from experts. Secondary data were also collected from national published report, ministries brief and policy guides. The study used predominate renewable energy resource for power generation such as solar, wind, hydro, geothermal and waste to energy. Based on the result, the country utilization of the resources like solar, wind and geothermal with less than $1 \%$ with respect to the potential except hydro power which is less than $9 \%$ from the national reserve. The paper found that finical, technical, policy and regulation are the main barriers that faced on the development renewable energy. Key measurements are strengthened finical institution, establishing capacity building center, initiation active community participation, organizing institution to support development of renewable energy. This proposed measurements and policy issues were based on the evidence faced the country.
\end{abstract}

doi: $10.5829 /$ ijee.2019.10.04.07

\section{INTRODUCTION}

\section{Renewable energy development status of Ethiopian energy}

Ethiopia country located on horn of Africa, high plateau with mountain and the Great Rift Valley is cross the country. The country also has different soil, climate and settlement pattern [1]. The country economy is based on agriculture, the agriculture activity is done by human with old farming tools [2]. The country population is estimated to be 99 million, more population is young with a median age of 18.6 years. From a total, $80 \%$ of the population lives in rural area [3]. The people use as a main energy source is from traditional biomass fuel, it covers share of $89 \%$ for primary energy use of a country [4]. Based on the data for energy supply and consumption from 1996-2010, the biomass energy share from $96 \%$ decreased to $92 \%$. This shows an energy shift from biomass to petroleum and electricity. It is also projected that by 2030 the biomass demand will decrease to $71.6 \%$. The demand for electricity and petroleum will increase to $5.8 \%$ and $22.6 \%$, respectively [5].

Many researchers are working on Ethiopian Energy Systems. The paper which is written in related Ethiopian power were assessed and summarize as follows. Potentials, opportunities and sustainable utilization were assessed in 2010 [6]. The paper assessed the renewable energy resource potential, opportunity and sustainability issue to meet the energy demand of the country. The paper address that, if the energy potential used properly, it will meet the energy demand of the country and the regions as a whole. The resources assessed in this paper was hydro, wind, solar and geothermal. It similar with the work but paper lacks to address the drives and barriers to use the energy resources.

One of the study conducted by Tucho et al. [7] is "Assessment of renewable energy resources potential for large scale and standalone applications in Ethiopia". In this paper, they have presented future energy resource of solar; also, wind and hydro were assessed. It is found that, Annual exploitable potentials for solar, wind and hydroelectric were 7.5 PWh, 4 PWh and 0.2 PWh, respectively. To correlate this paper with this current work is the driver and barriers to that hinder this reserve is not addressed. Plus, the geothermal and waste to renewable energy resource is not addressed.

Addition research was conducted, the paper entitled "Ethiopian power sector development: Renewable based universal electricity access and export strategies" [8]. The Ethiopian power sector alternative and long term supply strategies using the standard MARKAL energy model from year 2014 to 2045 were assessed. For this analyses renewable energy resources potential of hydro power, solar and wind were used. Development of renewable energy resource is a

\footnotetext{
*Corresponding Author Email: anta.energy@gmail.com (A. Belay Kassa)
} 
good option when compare to fossil fuel; the former take minimal cost while the earlier will provide long term environmental benefits. This paper will assess all the energy sources of all resource.

The main goal of this paper is to investigate the current status, future potential and barriers on development of renewable energy for power generation in Ethiopia. The paper could also provide as policy instrumentation and measures that can effectively contribute the remarkable growth of renewable energy technologies in the country.

\section{METHOD AND METHODOLOGY}

\section{Study area}

The study area covers the whole area of Ethiopia. The country covers a total of 1.13 Million Square Km with a GDP at market value $11 \%$ growth per annum (US\$ 30 Billion) [9]. Ethiopia is located in horn of Africa with latitude and longitude $9.1450^{\circ} \mathrm{N}$ and $40.4897^{\circ} \mathrm{E}$, respectively [10]. The country situated nearby Sudan, Kenya, Eritrea and Somalia (see Figure 1).

\section{Data collections}

For the study, primary and secondary data were collection. Secondary data were used from national, international literature, Ethiopian national energy policy, Growth and transformation plan document and reports published by officers in energy sector office. The primary data were collected by structural questionnaires' to energy experts and officers.

\section{Method of the study}

Based on standard methodology [11], the study was conducted. The method used was technical and policy assessments. Total technical potential and installed capacity of energy were assessed. This method was also used by other researchers as the details are reported in literature [12-17].

\section{RENEWABLE ENERGY DEVELOPMENT IN ETHIOPIA}

In Ethiopia Electricity is used for cooking and lighting purpose. Due to the gradual economic growth of the country. It is forced to increase, the use of energy in daily activity. To meet this energy demand of the people and to reduce challenge's, the government is forced to search alternative energy of solar, hydro, wind, geothermal and bio fuel [18]. Plenty of different renewable energy potential is available

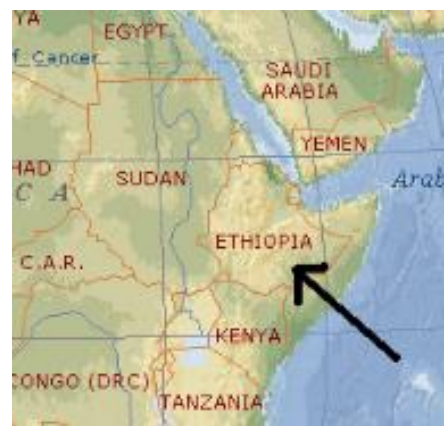

Figure 1. The location of Ethiopia in East of Africa [9] throughout the country. It isn't exploited more. Country energy productions till 2011 are shown in Table 1. Approximately $95 \%, 4.4 \%$ and $0.4 \%$ of the country power generation is from hydro power, thermal and geothermal, respectively [19].

After five-year duration, the energy mix uses are shown in the following Figure 2. The figure shows that the power generation $86 \%$ is found from hydro. When it compared with last five years, it was found with $10 \%$ share shaft. The rest $6 \%$ and $8 \%$ is from Thermal and from renewable energy sources (wind, solar and geothermal) respectively [20].

Access to modern energy technology is less in the country, this less access to modern energy hinder the socioeconomic development of the country [8]. Ethiopian electricity production from various sources in years $2011 / 12$ to $2014 / 15$ is tabulated in Table 2.

From the above table the energy production from 2011/12 to 2014/15 shows tremendously increased from 6.2 Million KWH to 9.5Million KWH, respectively. Except thermal and geothermal energy resources the other resources increased from time to time. On the other hand, in the last five years there was no geothermal plant developed. The thermal energy source shows fluctuation in the last four years [4].

Generally, the energy production was increased from time to time. The comparison between the current installed to the national reserve is can be tabulated in the following table. The resource data is exploited as 2015. The country potential energy resource and exploited amount is tabulated in Table 3.

TABLE 1. Ethiopian energy generation status and contributions [19]

\begin{tabular}{lcccc}
\hline & Thermal & Hydro & Geothermal & Total \\
\hline MW & 89.2 & 1945 & 7.2 & 2041.4 \\
\% Share & 4.4 & 95.2 & 0.4 & 100 \\
\hline
\end{tabular}

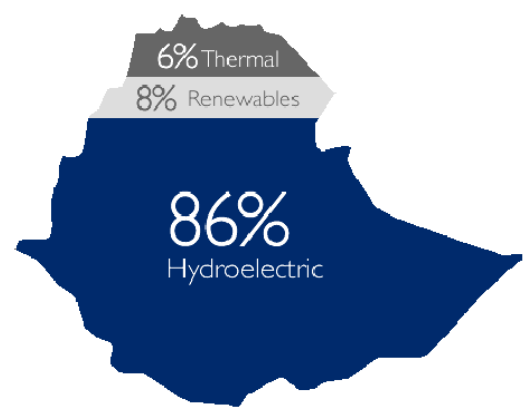

Figure 2. Ethiopian Current electric generation mix source [20]

TABLE 2. Ethiopian electricity production capacity sources [4]

\begin{tabular}{lcccc}
\hline \multicolumn{5}{c}{ Electrical power production capacity $(\mathbf{k W h})$} \\
\hline Source & $2011 / 12$ & $2012 / 13$ & $2013 / 2014$ & $2014 / 2015$ \\
Hydro power & 6241000.0 & $7385,659.6$ & 8336422.6 & $9014,010.6$ \\
Thermal power & 8101.1 & 10903.6 & 8837.0 & 7645.8 \\
$\begin{array}{l}\text { Geothermal } \\
\text { energy }\end{array}$ & 7699.3 & - & - & - \\
Wind energy & 29200.1 & 191784.7 & 355757.9 & 497690.8 \\
Total & 6286000.4 & 7588347.9 & 8701017.5 & 9519347.1 \\
\hline
\end{tabular}


TABLE 3. Ethiopian renewable energy potential source [21]

\begin{tabular}{cccc}
\hline Resource & Unit & $\begin{array}{c}\text { Exploitable } \\
\text { Reserve }\end{array}$ & $\begin{array}{c}\text { Exploited } \\
\text { in 2015 }\end{array}$ \\
\hline Hydropower & MW & 45,000 & $<9 \%$ \\
Solar & $\mathrm{kWh} / \mathrm{m} 2 /$ Day & 5.5 & $<1 \%$ \\
Wind & $\mathrm{GW}$ & 1,350 & $<1 \%$ \\
Geothermal & $\mathrm{MW}$ & 7000 & $<1 \%$ \\
Wood & Million tons & 1120 & $50 \%$ \\
Agricultural waste & Million tons & $15-20$ & $30 \%$ \\
\hline
\end{tabular}

\section{Hydro power development}

According to Ministry of Water Irrigation and Electricity Federal Democratic Republic of Ethiopia report [22] the figure has been improved and changed to $3810 \mathrm{MW}$. The existing site is with installed capacity is as follo koka (43.3MW), Awash II (32 MW), Awash III (32MW), Finchaa (134 MW), Melek Wakena (153MW), Tis Aby I (11.4MW), Tis Aby II (73MW), Gilgel Gibe (184MW), Tekeze (300MW), Gilgel Gibe II (420MW), Beles (460MW), Fincha Amerti Neshi (97MW) and Gibe III (1870MW). Currently nation grid from hydro is $3810 \mathrm{MW}$ which is $8.4 \%$ of from the national exploited reserve.

\section{Solar energy development}

According Master plans a country has $5.5 \mathrm{kWh} / \mathrm{m}^{2} /$ Day solar radiation which can be benefited from solar energy. In the country there is no big solar farms but now a day the solar is utilized in different forms. This solar energy is exploited by small off-grid component under rural electrification program the installed for schools, social institution's health institutions and Tele-com towers. With a time-frame of $2005-2010$ in Ethiopia a total of 6.5 MW solar PV is installed throughout the country with varies players [23]. This exploitation figure (number) is almost less than $1 \%$ from a total potential of a resource of the country.

\section{Wind energy development}

Current wind energy installed in the country are Ashegoda (120MW), Adama I (51MW) and Adama II (153 MW) [24]. A total of 324 MW was installed. Based on technical and economical aspect the potential exploited wind energy is 1350 Gigawatt. This figure is less $1 \%$ from total national reserve.

\section{Geothermal energy development}

Currently, the country has only one site under operation with 7.3 MW [25]. The country has a reserve of potential of $7000 \mathrm{MW}$. This energy contribution is less than $1 \%$ when compare to the national reserve.

\section{Biomass energy development}

In Ethiopia the first waste-to-energy facility was built in Addis Ababa. The Reppi plant expected to have a processing capacity of approximately 1400 tons of waste per day. The Reppi Facility is to process up to $1,000,000 \mathrm{~kg}$ of waste per day, with installed capability of producing a maximum waste of $1,400,000 \mathrm{~kg}$ per day that are to be collected by the Addis Ababa City Authority. It is able to reach the required capacity using one $25 \mathrm{MW}(25,000 \mathrm{KW})$ turbine.

\section{BARRIERS TO THE DEVELOPMENT OF RENEWABLE ENERGY IN ETHIOPIA}

In Ethiopia there are many barriers in the development of renewable energy technology. Generally, the barriers which hinder the development can be categorized as Policy and legal barriers; technical barriers and financial barriers.

\section{Policy and legal barriers}

a) Awareness and information

In Ethiopia information and awareness level of users, designers and promoters of renewable energy technology are limited. Promotion and use of renewable energy have positive impact to the environment and reduce the greenhouse gases. Among all available resources in the country solar, wind, hydro, geothermal and biomass, the developer and promoters are advocating only in small scale of biogas and solar PV. This happen due to lack of knowledge and skills. The users are not totally aware about the available technologies. If promotion and advocacy is done in the community, absolutely people will choose for daily energy needs.

b) Policies and regulations

The country in 2013 had drafted renewable energy policy. Based on the objective of the policy, the implementation rate is low. There is some conflict between the existing practice and on the policy so it should be revised. The opportunity like carbon funds and credits are the main benefit, but it is not used because of the policy problem.

\section{Technical barriers}

a) Renewable energy resource data

In Ethiopia, there is no organized data for all renewable energy resources. The presence national data is critical for planner, developer and researchers to assess and evaluate the techno-economics study. In Ethiopia, except the master plane of solar and wind energy other resources did not have adequate information in national and regional level.

b) Technical capacity

To install any renewable energy technologies, it is required to have technical knowledge and skills. In the country it is observed that there are lack of expert's. Even all the installed hydro power, wind and solar plants were installed and maintained by foreign experts except small scale solar home systems. In the country, there is no short term programs to train professionals on design and installations of the plants except biogas digesters. National biogas program project run under federal government teaches how to design, install and maintain biogas digesters. Even though, it is good initiation the program has been continuing with some limitations. It is not included to produce the spare parts of the biogas plant, the spare part is imported from China and India.

c) National quality and standards

The energy technology equipment should meet the quality and standard code of the country. The energy technology components are imported from foreign country like China, India and Italy. The quality of the product is the main factor for viable and market diffusion and accessible to the community. It is impossible to control the quality of products 
because of country economy is based on free market. The quality of the product is correlate with the investment cost and lifetime. In the market high quality products require high investment cost and low quality low cost.

In the country, most energy technology equipment importers did not import quality certified goods. Some investors which is working on solar importing in affiliation with governmental administrations structure outlet, they import solar goods with light African certificates.

\section{Financial barriers}

a) Financing the renewable energy projects

For design and implementation of renewable energy projects, the main constraint is rising/seeking investment cost. Banks and Institution's and community are the main actor to cover the initial capital. The institutions and banks also to promote to provide loan to the users, designers, promoters and investors. In the country the financing the renewable energy project is on earlier stage.

b) Institutional support to renewable energy projects Institutional support is the main thing to bond stakeholders on planning, adoption and diffusion of renewable energy projects. From initiation to financing (last stage) of renewable energy projects, institution will take the lion share. Establishing institutions like center Excellency based on the resource availability in the particular area is a good way to adopted and diffuse the energy technologies. The institutions will help in providing networking of stake holders, assist in financial seek (grant and loan), capacity building training, research (resource assessment), policy issue and strategy formulation.

c) Local participation and ownership of the energy projects In Ethiopia, participation of local community and ownership of the project is somewhat on infant stage. Participation and ownership of renewable energy projects will help for participation from fundraising to keep the plant safe. If the community actively participate from initiation to transferring ownership, the maintenance and sustainability issue will be easy.

\section{PROPOSED SOLUTIONS TO THE BARRIERS RENEWABLES ENERGY DEVELOPMENT IN ETHIOPIA}

\section{Policy and legal frameworks}

a) Awareness and information

On national and regional level there is energy concerned office. The effectiveness of the office on awareness creation and information dissemination is inadequate. This was happened due to different reasons. Financial and skill gap are from the main constraint deter to achieve the goal. Among all resource present in the country both institutions are working on some extent on solar and biogas technologies. Creating plate forum and workshops are methods used to share good practice for developer and users but in both offices this action is limited.

b) Policy and regulation

The current Ethiopian energy policy should be revised so as to answer the main concern and realities faced for sustainable development of the sector. The existed policy did not have clear regulation and not enforceable. The energy policy should be too rationalized to discoursing the facts and aims. The peoples should be benefited from the change of climate mitigation, environmental change and opportunity gained from promotion and mitigation measure.

\section{Appropriate technology transfer and capacity building}

a) Resource information

In the country there is no organized resource assessment data base. Except national master plan data of solar and wind which is published 2012. Others resources was not assessed and published in the concerned office in the country.

\section{b) Technical capacity}

The capacity building and skill gap training for technician both on national and regional levels. In the country there should be established in national or regional levels for capacity building on resource assessment, system design, installation and development renewable energy technologies. If the experts improved their knowledge and skill, they would be able to develop innovative method to promote renewable energy technologies.

\section{c) Quality and standards}

In the country there is poor quality and standard monitoring mechanism for imported products in solar and other energy technologies. The national standard authority should monitor the quality of products before they imported and distributed in the market. Keeping the standards of the products on installation and maintenance is good for promoting in the use of energy technology in the community. Because of no National quality regulation agency in the country other's imported less quality products by considering the low cost. This activity hinders the market penetration of products. The government should be able to set minimum standards and codes to grant the consumers to pay for high quality products.

\section{Financing mechanisms}

\section{a) Financing}

Promoters and developer should look finical source for any successfully implement renewable energy project. The backbone of any project is looking for finical source. In Ethiopia finical source implementing renewable energy project is World Bank, carbon trading and low interest international loans, this is for large power plant. The local banks are not showing the interest on financing the low investment projects.

\section{b) Institutional support}

On renewable energy development there are different actors, these actors should link each other using institutions. Actors on development energy technology are experts, designers, equipment supplies, source of financing and community mobilizations. In Ethiopia the project on to establish center of Excellency for wind solar and hydro, but they are not giving fruitful result for the users and experts. Generally, we can conclude that participation of the intuition is limited.

c) Local participation and ownership

Participation and ownership depends on the size of the 
project. In large power plant the participation on fundraising and purchasing of bonds in increased from time to time. The ownership is to government agency. For small power plant the participation of the community is low but if it is done its a good way to give ownership and expansion of power to the people.

\section{CONCLUSION AND RECOMMENDATION}

The country has been harassing energy from different source to improve the energy deficiency faced on every area. On the other hand, on this finding it is proved that, Ethiopia has vast renewable energy potential on solar, wind hydro, geothermal and biomass. The exploration rate was low when it is compare to the potential availability. Yet, the development of this renewable energy was hindered by different barriers. To summarizes barriers as technical skills, policy and regulation and non-technical. This paper review and analyzed the above barriers, it is found that above barriers, on one and other reason hinder the deployment of the renewable energy projects. The proposed solution also put on this paper, to tackle the challenges.

\section{REFERENCES}

1. Gartner, K., 2015. Liquid Assets, Institutions, Climate Change and Conflict: The Political Ecology of Water in Maji Moto Group Ranch, Narok South, Kenya A Case Study of Water-Related Conflict in a Maasai Community, Master's Thesis, Utrecht University, Netherlands.

2. Wolde-Ghiorgis, W., 2002. Renewable energy for rural development in Ethiopia: the case for new energy policies and institutional reform. Energy Policy, 30(11-12), pp.1095-1105.

3. Issa, M., 2016. Energy Report-Ethiopia. Embassy of Sweden, Addis Abeba.

4. Berhanu, M., Jabasingh, S.A. and Kifile, Z., 2017. Expanding sustenance in Ethiopia based on renewable energy resources-A comprehensive review. Renewable and Sustainable Energy Reviews, 75, pp.1035-1045.

5. Ethiopian National Energy Policy (2nd draft). (2013). Addis Ababa Ethiopian Minsitry of Water and Energy. http://www. lse.ac.uk/GranthamInstitute/wp-content/uploads/laws/1195b.pdf.

6. Guta, D. and Börner, J., 2017. Energy security, uncertainty and energy resource use options in Ethiopia: A sector modelling approach. International Journal of Energy Sector Management, 11(1), pp.91-117.

7. Tucho, G.T., Weesie, P.D. and Nonhebel, S., 2014. Assessment of renewable energy resources potential for large scale and standalone applications in Ethiopia. Renewable and Sustainable Energy Reviews, 40, pp.422-431

8. Mondal, M.A.H., Bryan, E., Ringler, C. and Rosegrant, M., 2017. Ethiopian power sector development: Renewable based universal electricity access and export strategies. Renewable and Sustainable Energy Reviews, 75, pp.11-20.
9. Derbew, D., 2013. Ethiopia's Renewable Energy Power Potential and Development Opportunities. Ministry of Water and Energy: Abu Dhabi, UAE.

10. Belay, A., 2018. The Study on the SWOT Analysis of Solar Energy in Ethiopia. Journal of Environmental Pollution and Management, 1(2), pp.1-5.

11. Karekezi, S., Kithyoma, W., Muthee, G., Manyara, E. and Lwimbuli, J., Renewables in East and Horn of Africa-The Potential Contribution of Cogeneration and Geothermal Technologies A Regional Assessment. Population (million), 67(23.3), pp.30-7.

12. Mfune, O. and Boon, E.K., 2008. Promoting renewable energy technologies for rural development in Africa: experiences of Zambia. Journal of Human Ecology, 24(3), pp.175-189.

13. Kiplagat, J.K., Wang, R.Z. and Li, T.X., 2011. Renewable energy in Kenya: Resource potential and status of exploitation. Renewable and Sustainable Energy Reviews, 15(6), pp.2960-2973.

14. Markova, D., Platikanov, S., Konstantinoff, M. and Tsankov, P., 2011. Opportunities for using renewable energy sources in Bulgaria. Contemporary Materials (Renewable energy sources), 2(2), pp.178-184.

15. Tomar, A.K.S. and Gautam, K.K., 2018. Renewable energy in India: current status and future prospects. International Journal of Engineering Science Invention, 7(6), pp.86-91.

16. Fashina, A., Mundu, M., Akiyode, O., Abdullah, L., Sanni, D. and Ounyesiga, L., 2019. The drivers and barriers of renewable energy applications and development in Uganda: a review. Clean Technologies, 1(1), pp.9-39.

17. Qin, J., 2018. The status and prospect of new energy and renewable energy in China. In AIP Conference Proceedings (Vol. 1971, No. 1), American Institute of Physics, pp.1-5.

18. Mulugetta, Y., 2008. Human capacity and institutional development towards a sustainable energy future in Ethiopia. Renewable and Sustainable Energy Reviews, 12(5), pp.1435-1450.

19. Kebede, S., 2013. Geothermal exploration and development in Ethiopia: Status and future plan. Presented at Short Course VIII on Exploration for Geothermal Resources, organized by UNU-GTP, GDC and KenGen, at Lake Bogoria and Lake Naivasha, Kenya, pp.1-26.

20. Abbott, L. 2016. Ethiopia Energy Sector Overview. http://www.usaid.gov/powerafrica.

21. Norad, C., Mapping of Ethiopian higher education institutions on clean energy, Senter for Oekonomisk Analyse (ECON), Norway.

22. Ministry of Water Irrigation and Electricity Ministry of Water Irrigation and Electricity, 2017. The Ethiopian Power Sector: A Renewable Future. Berlin Energy Transition Dialogue, Berlin.

23. Rogelj, J., McCollum, D.L. and Riahi, K., 2013. The UN's' Sustainable Energy for All'initiative is compatible with a warming limit of 2 C. Nature Climate Change, 3(6), pp.545-551.

24. Chen, Y., 2016. A Comparative Analysis: The Sustainable Development Impact of Two Wind Farms in Ethiopia. Working Paper No. 2016/7. China-Africa Research Initiative, School of Advanced International Studies, Johns Hopkins University, Washington, DC.

25. Teklemariam, M. and Kebede, S., 2010, April. Strategy for geothermal resource exploration and development in Ethiopia. In Proceedings World Geothermal Congress, Indonesia, pp. 25-30. 
اتيويى كشورى است كه در شاخ آفريقا واقع شده است و توليد برق كشور ياسخكوى تقاضاى ملى مردم نيست. هدف اين مقاله بررسى وضعيت فعلى، پتانسيلهاى

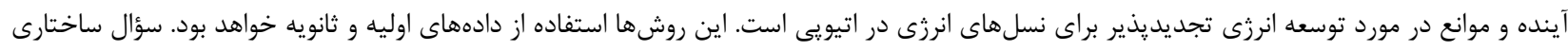

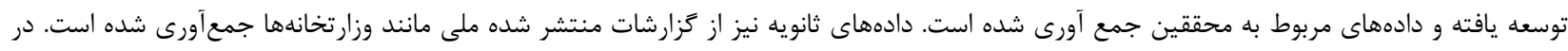

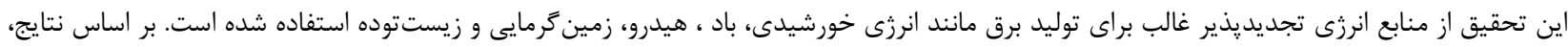

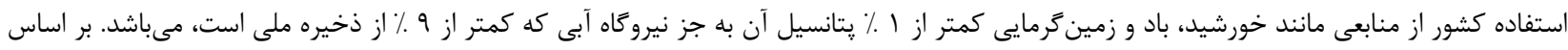

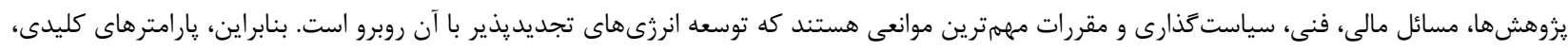

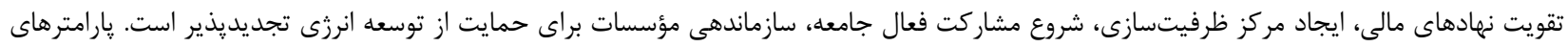

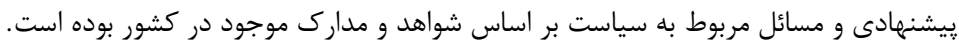

